Journal of Development and Social Change, Vol. 2, No. 1, April 2019

p-ISSN 2614-5766, https://jurnal.uns.ac.id/jodasc

\title{
PEMBINAAN KENAKALAN ANAK OLEH YAYASAN SINAI DI SUKOHARJO
}

\author{
Agustin Fatikasari $^{1}$, Supriyadi $^{2}$ \\ Program Studi Sosiologi Fakultas Ilmu Sosial dan Politik \\ Universitas Sebelas Maret Surakarta Indonesia \\ Email $^{1}$ : agustinfatika@gmail.com,Email² : supriyadi53@staff.uns.ac.id
}

\begin{abstract}
Juvenile delinquency is getting more worrying in both developed and developing countries over times. Juvenile delinquency is also a problem with which any family often complains. One of attempts to be taken to deal with juvenile delinquency is to conduct rehabilitation or mentoring. This research aimed to analyze the type of juvenile delinquency and its cause, to find out the form of building and the factors supporting and inhibiting the mentoring. This research employed Max Weber's Social Action theory. This qualitative research with case study was conducted in Sukoharjo. The sampling technique employed was purposive sampling technique. The informant of research consists of Chairperson and Mentors of Children in SINAI Foundation of Sukoharjo, and children who have ever committed delinquency and live in SINAI Foundation. Data was collected through observation, in-depth interview, and documentation. To validate the data, source triangulation was used. Technique of analyzing data used was Miles and Huberman's interactive analysis model. The result of research showed that type of delinquency committed by children residing SINAI Foundation is non-conform action including escaping from home or foundation and playing truant, and antisocial or asocial action including not paying transportation ticket or cost when going by public transportation and large vehicles crossing the road. The cause of delinquency committed by children residing SINAI Foundation included internal and external factors. Internal factor included wish coming from inside. External factor included family environment, economic condition, and friendship environment. The form of children mentoring conducted by SINAI foundation included mental spiritual building, skill building, and discipline building. The factor supporting the mentor was a belief inside assuming that mentoring the needy children was the form of worship to God and that fellow human beings should help each other. Meanwhile the factors supporting the child to attend the mentoring were the presence of complete and feasible facilities for residence and the fulfilled daily need, the access to education and the presence of friends or relatives living there. The factor inhibiting the Mentor included queer SINAI Foundation resident's queer behavior and sometimes accident occurring during mentoring or treatment. The factor inhibiting the children attending the mentoring was the Mentor's resoluteness making them sometimes upset and longing for seeing their parents.
\end{abstract}

Keywords: Delinquency, Child, Mentoring

Abstrak: Permasalahan kenakalan anak semakin lama semakin meresahkan baik di Negara maju maupun di Negara berkembang. Kenakalan pada anak juga merupakan permasalahan yang sering dikeluhkan oleh setiap keluarga. Salah satu cara yang bisa dilakukan untuk mengatasi kenakalan anak dengan adanya sarana rehabilitasi atau pembinaan. Tujuan penelitian ini untuk menganalisis jenis kenakalan anak dan penyebabnya, untuk mengetahui bentuk pembinaan serta faktor pendorong dan penghambat dalam pembinaan. Penelitian ini menggunakan teori Tindakan Sosial dari Max Weber. Penelitian kualitatif dengan pendekatan studi kasus ini dilakukan di Sukoharjo. Teknik pengambilan sampel dengan teknik purposive sampling. Adapun informan penelitian terdiri dari ketua dan Pembina anak-anak di Yayasan SINAI Sukoharjo, serta anak-anak yang pernah melakukan kenakalan dan tinggal di Yayasan 
SINAI. Data dikumpulkan dengan observasi, wawancara mendalam dan dokumentasi. Untuk menguji validitas data dengan triangulasi sumber. Teknik analisis data menggunakan model analisis interaktif dari Miles dan Huberman.

Hasil penelitian menunjukkan bahwa jenis kenakalan yang dilakukan oleh anak-anak penghuni Yayasan SINAI adalah tindakan nonconform meliputi melarikan diri dari rumah atau dari yayasan dan membolos sekolah, serta tindakan anti sosial atau asocial meliputi tidak membayar tiket atau biaya transport saat naik kendaraan umum dan menumpang kendaraankendaraan besar yang melintas di jalan. Penyebab kenakalan yang dilakukan anak penghuni Yayasan SINAI yaitu faktor internal dan eksternal. Faktor internal, yaitu adanya keinginan dari dalam dirinya sendiri. Faktor eksternal, meliputi lingkungan keluarga, keadaan ekonomi, lingkungan pertemanan. Bentuk pembinaan Yayasan SINAI terhadap anak yang melakukan kenakalan meliputi pembinaan mental spiritual, pembinaan ketrampilan, dan pembinaan kedisiplinan. Faktor pendorong bagi Pembina yaitu karena adanya keyakinan dari dalam diri bahwa membina anak-anak yang membutuhkan merupakan ibadah kepada Tuhan dan keyakinan bahwa sesama manusia itu harus saling membantu. Sedangkan faktor pendorong bagi anak untuk mengikuti pembinaan yaitu karena adanya fasilitas yang lengkap dan layak untuk tempat tinggal serta terpenuhinya kebutuhan sehari-hari, adanya akses pendidikan dan adanya teman atau saudara yang tinggal disana. Faktor penghambat bagi Pembina yaitu karena adanya tingkah laku yang aneh dari penghuni Yayasan SINAI dan terkadang juga terjadi kecelakaan saat membina atau pun merawat. Sedangkan faktor penghambat bagi anakanak yang mengikuti pembinaan yaitu karena sikap Pembina yang tegas sehingga anak-anak kadang merasa kesal dan adanya rasa rindu atau keinginan bertemu dengan orang tua.

Kata Kunci: Kenakalan, Anak, Pembinaan

\section{PENDAHULUAN}

Permasalahan kenakalan anak semakin lama semakin meresahkan baik di Negara maju maupun di Negara berkembang. Masyarakat Indonesia juga ikut merasakan keresahan tersebut, utamanya di kota-kota besar. Kenakalan pada anak juga merupakan permasalahan yang sering dikeluhkan oleh setiap keluarga. Hal tersebut telah menjadi masalah sosial serius yang dihadapi masyarakat. Terlebih lagi kasus-kasus kenakalan anak semakin meningkat dan tidak hanya dalam bentuk ringan namun juga meresahkan masyarakat.

Kartini Kartono berpendapat bahwa Juvenile Delinquency atau kenakalan anak adalah perilaku jahat (dursila), atau kejahatan/kenakalan anak-anak muda; merupakan gejala sakit (patologis) secara sosial pada anak-anak dan remaja yang disebabkan oleh satu bentuk pengabdian sosial, sehingga mereka itu mengembangkan bentuk tingkah laku yang menyimpang (Kartono, 2014).

Berdasarkan berita dari kpai.go.id pada 24 Februari 2018, sejumlah kasus kekerasan yang terjadi pada anak belakangan marak di tanah air. Komisi Perlindungan Anak Indonesia atau KPAI mencatat dalam 7 tahun terakhir angka kasus kekerasan anak mencapai 26.954 kasus. Kasus tertinggi adalah kasus anak yang berhadapan hukum baik sebagai pelaku maupun korban yang mencapai 9.266 kasus. Dan dilansir dari plus.kapanlagi.com pada Jum'at, 17 Maret 2017, berdasarkan data Badan Narkotika Nasional, justru 50-60\% remaja malah jadi pengguna narkoba. $48 \%$ dari jumlah tersebut merupakan pecandu sementara sisanya hanya mencoba penggunaan narkoba.

Tanpa disadari, penyebab anak melakukan kenakalan karena keadaan sekitar termasuk keluarga kurang memiliki kepedulian terhadap anak. Seharusnya anak mendapatkan perlakuan yang baik dan mendapatkan hak-hak yang mereka miliki. Namun kenyataannya yang terdapat di masyarakat bahwa tidak semua anak mendapatkan hak yang sebagaimana 
mestinya, baik dalam pemenuhan kebutuhan hidupnya ataupun hak mendapatkan kasih sayang dari orang tuanya. Ada diantara mereka yang mengalami keterbatasan dalam mendapatkan hak tersebut sehingga ia menjadi anak yang terlantar. Akibatnya mereka menjadi tidak terpenuhi kebutuhannya, baik secar fisik, psikis dan kebutuhan lainnya. Sebagai suatu masalah sosial, anak yang melakukan kenakalan perlu penanganan yang serius agar tidak bertambah jumlahnya dari tahun ke tahun dan tidak berdampak negatif pada kehidupan masyarakat.

Untuk mengurangi bertambahnya kenakalan anak perlu adanya pencegahan sejak dini kepada anak-anak yang sudah rentan melakukan kenakalan. Anak-anak yang rentan melakukan kenakalan akan meresahkan masyarakat karena mereka tidak memiliki aktivitas sehari-hari yang bermanfaat. Selain itu perekonomian keluarga anak yang rentan melakukan kenakalan cenderung rendah, sehingga kemungkinan tindakan melanggar norma akan di lakukan oleh anak-anak tersebut. Tentu saja kenakalan yang dilakukan oleh anak sudah sangat bervariasi. Mulai dari kenakalan yang berat seperti pencurian, pemerkosaan dan pembunuhan maupun kenakalan yang ringan seperti membolos sekolah dan pergi tanpa ijin.

Anak adalah seseorang yang belum berusia 18 tahun, termasuk anak yang masih dalam kandungan terdapat dalam Undang-Undang Pemerintah Indonesia Nomor 23 Tahun 2002 Tentang Perlindungan Anak. Dengan melihat kondisi demikian, anak sebagai generasi penerus bangsa dan sekaligus sebagai aset sebuah bangsa harusnya didik, diasuh, dirawat, dilindungi, dan dibimbing supaya nilai guna menjadi sebuah aset bangsa dapat ditingkatkan. Oleh sebab itu, anak sebagai generasi muda perlu mendapatkan kesempatan penuh untuk tumbuh dan berkembang yang wajar baik secara fisik maupun psikis. Dan untuk mengatasi masalah kenakalan yang dilakukan oleh anak, perlu dilakukan adanya penanggulangan secara preventif dan represif.

Banyak cara yang bisa dilakukan untuk membentuk kepribadian anak agar sesuai dengan perilaku di masyarakat. Salah satu cara yang bisa dilakukan dengan adanya sarana rehabilitasi. Sarana rehabilitasi adalah salah satu metode yang digunakan sebagai upaya mengembalikan mereka pada norma-norma yang berlaku. Sarana rahabilitasi merupakan bentuk dari panti sosial, tentunya hal ini dilakukan agar tidak terlanjur menjadi anak yang brutal. Masyarakat juga harus berpartisipasi untuk menjadikan generasi muda sebagai penerus bangsa yang baik. Contohnya dengan memasukkan anak-anak jalanan, anak nakal, anak terlantar kedalam panti sosial.

Yayasan SINAI yang berada di Kabupaten Sukoharjo merupakan salah satu panti rehabilitasi sosial yang menampung anak-anak terlantar yang sebagian besar pernah melakukan kenakalan. Yang mana memiliki tujuan untuk ikut serta membantu pemerintah dalam rangka mewujudkan pembangunan nasional di bidang sosial masyarakat dan bidang kerohanian. Cara yang dilakukan Yayasan SINAI untuk mencapai tujuannya yaitu dengan melakukan pembinaan kepada para penghuninya termasuk anak-anak.

Pembinaan adalah upaya pendidikan formal maupun non formal yang dilakukan secara sadar, berencana, terarah, teratur, dan bertanggung jawab dalam rangka memperkenalkan, menumbuhkan, membimbing, dan mengembangkan suatu dasar-dasar kepribadiannya seimbang, utuh dan selaras, pengetahuan dan keterampilan sesuai dengan bakat, kecenderungan/keinginan serta kemampuan-kemampuannya sebagai bekal, untuk selanjutnya atas perkasa sendiri menambah, meningkatkan dan mengembangkan dirinya, sesamanya maupun lingkungannya ke arah tercapainya martabat, mutu dan kemampuan manusiawi yang optimal dan pribadi yang mandiri (Simanjuntak, 1990). 
Penelitian ini memfokuskan pada pembinaan yang dilakukan oleh Yayasan SINAI terhadap anak-anak yang pernah melakukan kenakalan. Anak-anak terlantar yang memiliki masa lalu sangat beragam dan perlu mendapatkan pembinaan untuk kehidupan selanjutnya.

Melihat permasalahan yang telah diuraikan, peneliti tertarik untuk mengadakan penelitian di Yayasan SINAI Sukoharjo dengan judul penelitian "Pembinaan Kenakalan Anak Oleh Yayasan SINAI di Sukoharjo".

\section{METODE PENELITIAN}

Penelitian ini menggunakan metode kualitatif dengan pendekatan studi kasus yang dilakukan di Yayasan SINAI yang terletak di Sukoharjo. Dalam penelitian ini, teknik penentuan informan dilakukan secara purposive sampling. Teknik analisis data yang digunakan dalam penelitian ini adalah teknik analisis model Analisis Interaktif dari Miles Huberman. Model Analisis Interaktif dari Miles Huberman ini terdiri dari tiga tahapan yang disebut dengan Analisis Interaktif yaitu pengumpulan data, reduksi data, penyajian data, dan penarikan kesimpulan. Pengumpulan data dilakukan dengan observasi, wawancara dan dokumentasi selama peneliti berada di lapangan. Data pendukung berasal dari jurnal ilmiah dan dokumen terkait yang memiliki tema serupa. Untuk validitas data dilakukan dengan teknik triagulasi sumber yaitu triangulasi yang digunakan untuk menguji kredibilitas data dengan cara mengecek data yang telah diperoleh melalui beberapa sumber. Triangulasi sumber dari penelitian ini diperoleh dengan melakukan cross-check informasi antar informan yang satu dengan informan yang lain. Jumlah keseluruhan informan yang digunakan dalam penelitian ini adalah 8 orang. Informan kunci dalam penelitian ini adalah Ketua Yayasan SINAI. Sedangkan informan utama adalah anak-anak yang pernah melakukan kenakalan yang tinggal di Yayasan SINAI. Adapun informan pendukung adalah Pembina di Yayasan SINAI.

\section{HASIL DAN PEMBAHASAN}

\section{Jenis Kenakalan yang Dilakukan Anak Penghuni Yayasan SINAI}

Anak-anak terlantar disini berasal dari anak-anak jalanan dan anak yang kurang mampu. Yang mana mereka pernah melakukan kenakalan, baik ketika sebelum tinggal di Yayasan SINAI maupun ketika sudah tinggal disana. Kenakalan yang dilakukan anak-anak di Yayasan SINAI ini berbeda-beda. Peneliti menggunakan konsep dari Narwoko (2007) untuk mengidentifikasikan bentuk-bentuk kenakalan. Berdasarkan hasil penelitian, bentuk-bentuk kenakalan yang dilakukan anak-anak di Yayasan SINAI yaitu tindakan nonconform dan anti sosial atau asocial. Tidak ditemukan anak yang melakukan tindakan kriminal.

Tindakan nonconform meliputi melarikan diri dari rumah atau dari yayasan dan membolos sekolah. Karena tindakan tersebut tidak sesuai dengan nilai-nilai dan norma-norma yang ada. Melarikan diri dari rumah merupakan perilaku yang dianggap tidak baik oleh masyarakat dan meresahkan keluarganya. Pergi dari Yayasan SINAI juga membuat resah para Pembina. Mereka juga melanggar aturan Yayasan SINAI, yaitu wajib ijin kepada Pembina apabila ingin pergi. Sebagai siswa juga tidak boleh membolos, apabila tidak masuk seharusnya dengan alasan yang sebenarnya, tidak berbohong. Membohongi orang tua (pembina) juga merupakan perbuatan yang tidak baik atau tidak sopan.

Sedangkan tindakan anti sosial atau asocial meliputi tidak membayar tiket atau biaya transport saat naik kendaraan umum dan menumpang kendaraan-kendaraan besar yang melintas di jalan. Karena tindakan tersebut merupakan kegiatan yang dilarang, pada aturannya setiap penumpang kendaraan umum harus membayar biaya transportnya sehingga 
melawan kebiasaan masyarakat atau kepentingan umum. Seharusnya kendaraan besar juga tidak membawa penumpang dibelakang, dan tindakan tersebut berbahaya jika dilakukan.

Kenakalan yang dilakukan oleh anak-anak penghuni Yayasan SINAI jika menurut konsep dari Kartini Kartono (2014) merupakan kenakalan terisolir (delinkuensi terisolir). Kelompok ini merupakan jumlah terbesar dari remaja nakal. Pada umumnya mereka tidak menderita kerusakan psikologis.

\section{Penyebab Kenakalan Anak}

Dari beberapa anak yang melakukan kenakalan, memiliki penyebab yang berbedabeda. Penyebab dari kenakalan yang mereka tidak hanya berasal dari diri mereka sendiri, tetapi juga berasal dari luar antara lain, kondisi keluarga dan lingkungan pertemanan. Maka peneliti melihat dari dua segi, yaitu dari segi internal (dalam diri) dan dari segi eksternal (luar diri).

a. Faktor internal (dalam diri)

Faktor internal ini merupakan alasan anak melakukan suatu kenakalan yang berasal dari dalam diri anak tersebut. Perilaku tersebut muncul bisa karena sifat egoisme anak yang mendominasi dan mendorong anak tanpa sadarkan diri. Anak-anak bisa juga melakukan kenakalan karena kenginannya sendiri dengan sadar ingin melakukan. Perasaan keingintahuan anak juga bisa mendorong untuk melakukan perilaku yang melanggar norma, selain itu juga bisa didasari karena kondisi kejiwaan yang terganggu.

Dalam penelitian ini, ditemukan bahwa beberapa anak memiliki dorongan untuk melakukan kenakalan. Seperti ingin pergi dari rumah atas keinginan dirinya sendiri. Keinginan tersebut muncul karena adanya ancaman dalam keluarga, dan semakin lama dorongan untuk kabur dari rumah semakin kuat. Anak memutuskan untuk pergi dari rumah karena dirinya tidak menerima aturan yang berlaku di rumah tempat dia tinggal. Ketika melarikan diri dari panti, ada juga yang berdasarkan keinginan sendiri bahkan mengajak teman-teman yang lain untuk ikut pergi. Penyebab dari internal juga terjadi pada anak yang membolos. Anak melakukan perilaku ini karena dorongan dari dalam dirinya. Dirinya tidak ingin berangkat ke sekolah karena rasa malas yang muncul dari dalam dirinya.

b. Faktor Eksternal

Faktor Eksternal ini berasal dari luar diri individu. Dorongan dari luar itu bisa didasari karena keadaan ekonomi, keadaan lingkungan baik keluarga maunpun pertemanan, ataupun hal lain dari luar diri mereka. keadaan diluar diri anak tersebut bisa mempengaruhi anak untuk melakukan kenakalan.

Anak melarikan diri dari rumah juga didasari oleh keadaan lingkungan keluarga yang membuat dia tidak nyaman karena selalu dimarahi akibat perbuatan yang pernah dia lakukan. Kondisi lingkungan juga memperkuat keinginan anak untuk melarikan diri dari rumah. Lingkungan yang dimaksud adalah lingkungan pertemanan. Teman-teman sepermainan memiliki keinginan yang sama dan mempengaruhi anak untuk melakukan tindakan tersebut. Beberapa anak yang pernah melarikan diri dari Yayasan SINAI juga didasari oleh faktor eksternal. Mereka melakukan kenakalan tersebut karena ingin mengikuti teman yang lain. Mereka sebenarnya tidak memiliki keinginan untuk melarikan diri, namun karena temantemannya berencana untuk melarikan diri maka mereka ikut.

Perilaku menaiki kendaraan umum tanpa membayar biaya transport dilakukan oleh anak karena keadaan ekonomi. Ketika anak tinggal di jalanan, keadaan ekonomi dalam kondisi yang tidak baik. Anak harus mempertahankan diri berpindah-pindah kota untuk mengemis, tetapi dia tidak mempunyai biaya untuk membayar tiket. Hal ini juga yang mendasari anak sering menumpang kendaraan besar yang melintas di jalan. 


\section{Bentuk Pembinaan}

Pembinaan merupakan cara yang dilakukan oleh Yayasan SINAI untuk membentuk kepribadian anak-anak agar tidak melakukan kenakalan lagi. Kegiatan pembinaan yang dilakukan oleh Yayasan SINAI meliputi pembinaan mental spiritual, kedisiplinan, dan ketrampilan. Pembinaan mental spiritual meliputi kegiatan ibadah sesuai dengan ajaran agama. Pembiaan kedisiplinan yaitu diterapkan dalam kegiatan sehari-hari anak yang teratur dan tanggung jawab. Sedangkan pembinaan ketrampilan meliputi kegiatan kesenian, seperti menyanyi, menari dan sebagainya.

Terpenuhinya kebutuhan jasmani, rohani serta sosial bagi anak-anak yang pernah melakukan kenakalan merupakan upaya untuk merubah perilaku anak melalui kegiatan pembinaan. Pembinaan dalam panti merupakan cara yang cukup efektif agar anak-anak tidak mengulangi kenakalan yang pernah dilakukan.

Berikut pelaksanaan pembinaan kenakalan anak yang dilakukan Yayasan SINAI meliputi:

a. Pembinaan Mental Spiritual

Pembinaan mental spiritual dipilih oleh Yayasan SINAI sebagai pembinaan utama bagi anak-anak yang tinggal disana. Materi yang diberikan dalam pembinaan ini ditentukan oleh Pembina. Anak-anak hanya pengikuti arahan dari Pembina. Pembinaan ini wajib diikuti oleh semua penghuni Yayasan SINAI termasuk anak-anak.

Materi yang diberikan bersumber dari ajaran Alkitab untuk yang beragama Nasrani. Untuk penghuni yayasan yang tidak beragama nasrani juga diarahkan untuk belajar sesuai ajaran agama masing-masing. Penghuni Yayasan SINAI dibina dan diarahkan untuk mengenal Tuhan secara baik dan benar sesuai keyakinan masing-masing. Anak-anak juga diajarkan untuk menjadi pribadi yang lebih baik dalam kehidupan sehari-hari. Selain itu juga diajarkan melakukan hal-hal baik kepada orang lain, seperti membantu sesama. Pembina juga memberikan motivasi kepada penghuni Yayasan SINAI berdasarkan pengalamanpengalaman dalam hidup mereka. motivasi tersebut untuk memberikan semangat agar mereka semangat menjalani hidup dan tidak putus asa mencapai cita-cita. Pembina dalam memberikan ceramah pada kegiatan ibadah ini berpedoman pada Alkitab yang menjadi pedoman agama nasrani.

Metode dalam pembinaan mental spiritual diberikan dengan berbagai macam. Yang pertama ceramah, kedua dengan sharing, dan yang ketiga dengan memberikan tugas. Ceramah diberikan langsung oleh Pembina, satu Pembina memberikan pembinaan dengan cara ceramah kepada seluruh penghuni yayasan. Sharing dilakukan bersama-sama semua penghuni Yayasan SINAI dengan membentuk kelompok yang isinya campuran dari anakanak sampai dewasa. Dalam kelompok ini mereka saling bercerita pengalaman satu sama lain. Dari cerita teman lain, para penghuni Yayasan SINAI bisa mengambil pelajaran dan saling membantu satu sama lain. Penghuni Yayasan SINAI diberi tugas yang berhubungan dengan materi yang pernah disampaikan dalam kegiatan ibadah, dengan tugas tersebut mereka lebih memahami materi yang telah disampaikan.

Waktu pelaksanaan kegiatan pembinaan juga sudah ditentukan oleh Pembina. Dalam pembinaan ini, Pembina lebih menekankan untuk mengajak anak-anak sejak dini melakukan ibadah secara rutin. Yang mana kebanyakan dari anak yang tinggal di Yayasan SINAI beragama Nasrani, maka ibadah rutin selalu diadakan 4 kali setiap pekan. kegiatan ibadah dilakukan setiap hari Selasa, Rabu, Jumat dan hari Minggu. Setiap harinya, metode yang digunakan pun berbeda-beda. Dari metode ceramah, sharing dan diselingi dengan permainan- 
permainan agar menarik bagi anak-anak. Untuk memperdalam materi yang telah diajarkan, anak-anak juga diberikan tugas yang bisa juga mengasah kreatifitas mereka.

Selain ibadah yang rutin dilakukan bersama, anak-anak juga diajarkan untuk doa sehari-hari yang mereka sebut biston dan cepel. Bagi penghuni yayasan yang tidak beragama Nasrani juga diarahkan untuk menjalankan kewajiban ibadah rutin sesuai keyakinan yang mereka anut, seperti sholat 5 waktu bagi yang muslim. Anak-anak juga diajak puasa bersama setiap hari Rabu.

Dengan bimbingan melalui ibadah ini diharapkan anak lebih taat menjalankan ajaran agama. Pembina mengajarkan anak agar lebih mengenal Tuhan, dan juga bagainama agar Tuhan mengenal mereka. karena menurut mereka dengan begitu akan menjadi manusia yang lebih baik. Diharapkan juga nak-anak mengamalkan ajaran agama dalam kegiatan sehari-hari. Dengan mengamalkan ajaran agama diharapkan anak-anak tidak akan mengulangi perbuatannya yang dulu yaitu perilaku yang menyimpang.

b. Pembinaan Ketrampilan

Untuk pembinaan ketrampilan anak-anak diberi kebebasan untuk memilih ketrampilan apa yang akan mereka pelajari. Waktu untuk mengasah ketrampilan ini juga bisa kapan saja. Tidak ada jadwal tertentu untuk anak-anak, mereka biasanya belajar ketrampilan selain pelajaran sekolah yaitu pada siang hari setelah mereka pulang sekolah. Dari pihak yayasan memberikan fasilitas untuk anak-anak mengembangkan diri. Untuk mengasah ketrampilan, anak-anak bisa memanfaatkan fasilitas yang ada sesuai dengan keinginan mereka.

Dari kegiatan ini nantinya akan menjadi keahlian tersendiri bagi mereka. Pihak Yayasan juga mendukung dan menyediakan wadah untuk mereka menampilkan keahliannya. Tidak hanya bisa membanggakan Yayasan, namun dengan mereka memiliki keahlian tersebut juga bisa mewakili sekolah dalam perlombaan.

Selain bekal pengetahuan umum yang didapat dari sekolah dan pengetahuan agama dari pembinaan mental spiritual, anak-anak diharapkan juga memiliki keahlian lain yaitu berbagai ketrampilan. Dengan pembinaan ketrampilan ini akan dapat menyalurkan dan mengembangkan hobi yang anak-anak miliki.

c. Pembinaan Kedisiplinan

Pembinaan kedisiplinan diajarkan langsung dengan praktek. Melalui kegiatan seharihari, pembinaan kedisiplinan diajarkan kepada anak. Setiap kegiatan yang ada di Yayasan SINAI sudah terjadwal dan terstruktur. Mulai dari bangun pagi, doa pagi, membereskan tempat tidur, bersih-bersih diri, sarapan, dan dilanjutkan sekolah. Sepulang sekolah mereka diberi kebebasan untuk bermain. Jika ada jadwal ibadah mereka wajib mengikuti. Kemudian sore harinya mereka belajarbersama-sama di kamar. Anak-anak juga diajarkan untuk mandiri, seperti mencuci baju dan menyetrika sendiri. Anak-anak diajarkan kedisiplinan dengan mengikuti kegiatan sesuai waktu yang telah ditentukan. Dengan adanya pembinaan kedisiplinan ini diharapkan anak-anak bisa menjalani kehidupan yang teratur dan kebiasaan yang positif.

Dari pembinaan yang diterapkan oleh Yayasan SINAI, ada perubahan sikap anakanak yang dapat dirasakan sedikit demi sedikit. Anak-anak menerapkan ajaran dari yang disampaikan Pembina yaitu dengan membantu Pembina menyiapkan makanan dan bersihbersih. Ketrampilan yang anak-anak miliki juga memberikan dampak baik bagi mereka. Anak bisa berprestasi dan membanggakan sekolah, yayasan dan diri mereka sendiri. Salah satu prestasi yang didapatkan anak penghuni Yayasan SINAI yaitu mewakili sekolahnya mengikuti perlombaan menyanyi yang diadakan Kabupaten Sukoharjo. Dengan kehidupan yang teratur, anak-anak yang semula hidup dijalanan dan tidak banyak aturan mengalami 
berbagai perubahan. Perubahan tersebut mengarah ke hal yang positif yaitu anak-anak menjadi tertib dalam kehidupan sehari-hari.

\section{Faktor Pendorong dan Faktor Penghambat}

Faktor pendorong dan penghambat adalah penyebab yang mempengaruhi pelaksanaan pembinaan di Yayasan SINAI baik secara positif maupun negatif. Faktor-faktor ini dilihat dari Pembina dan anak-anak penghuni panti.

Menurut hasil wawancara dan pengamatan di lapangan maka dapat dikatakan bahwa dalam pelaksanaan pembinaan anak-anak di Yayasan SINAI memiliki faktor pendorong dan penghambat. Faktor-faktor tersebut muncul dari para anak yang tinggal di Yayasan SINAI maupun dari para pembinanya sendiri.

- Faktor Pendorong

Bagi Pembina Yayasan SINAI faktor-faktor yang menyebabkan mereka tetap semangat dalam membina anak-anak di Yayasan SINAI karena ada beberapa hal, antara lain:

1. Adanya keyakinan dari dalam diri bahwa membina anak-anak yang membutuhkan merupakan ibadah kepada Tuhan.

2. Adanya keyakinan dari dalam diri mereka bahwa sesama manusia itu harus saling membantu.

Sedangkan bagi anak-anak yang tinggal di Yayasan SINAI, faktor-faktor yang menyebabkan anak-anak senang tinggal di Yayasan SINAI karena beberapa hal, antara lain:

1. Adanya fasilitas yang lengkap dan layak untuk tempat tinggal serta terpenuhinya kebutuhan sehari-hari.

2. Adanya akses pendidikan.

3. Adanya teman atau saudara yang tinggal disana.

- Faktor Penghambat

Adapun faktor penghambat bagi Pembina dalam pelaksanaan pembinaan meliputi:

1. Adanya tingkah laku yang aneh dari penghuni Yayasan SINAI

2. Terkadang juga terjadi kecelakaan saat membina atau pun merawat

Faktor penghambat bagi anak-anak penghuni Yayasan SINAI antara lain:

1. Sikap Pembina yang tegas sehingga anak-anak kadang merasa kesal, seperti dimarahin.

2. Adanya rasa rindu atau keinginan bertemu dengan orang tua

Tabel 4.7 Faktor Pendorong dan Penghambat Pembinaan

\begin{tabular}{|l|l|}
\hline \multicolumn{4}{|c|}{ Faktor Pendorong dan Penghambat Pembinaan } \\
\hline $\begin{array}{l}\text { Faktor Pendorong } \\
\text { Ibadah kepada Tuhan dan keyakinan }\end{array}$ & $\begin{array}{l}\text { Faktor Penghambat } \\
\text { Tingkah laku yang aneh dari } \\
\text { bahwa sesama manusia itu harus } \\
\text { saling membantu. (Pembina) }\end{array}$ \\
Fasilitas yang lengkap dan layak & $\begin{array}{l}\text { kecelakaan saat membina atau pun } \\
\text { merawat. (Pembina) }\end{array}$ \\
untuk tempat tinggal serta & $-\begin{array}{l}\text { Sikap Pembina yang tegas } \\
\text { terpenuhinya kebutuhan sehari-hari, } \\
\text { adanya akses pendidikan dan adanya } \\
\text { teman atau saudara yang tinggal } \\
\text { disana. (Anak) }\end{array} \quad \begin{array}{l}\text { kesal dan adanya rasa rindu atau } \\
\text { keinginan bertemu dengan orang } \\
\text { tua. (Anak) }\end{array}$ \\
\hline
\end{tabular}


Berdasarkan hasil analisis peneliti, dalam melakukan pembinaan anak yang melakukan kenakalan, yayasan dan pembina menggunakan tindakan sosial yang berbeda. Yayasan dalam melakukan pembinaan menggunakan rasionalitas instrumental (Zwerk Rational). Rasionalitas instrumental (Zwerk Rational) Jenis Tindakan sosial Rasional instrumental ini merupakan tindakan yang memiliki rasionalitas paling tinggi, yang meliputi pilihan yang sadar (masuk akal) yang berhubungan dengan tujuan tindakan itu dan alat yang dipergunakan untuk mencapainya. Individu dilihat sebagai memiliki macam-macam tujuan yang mungkin diinginkannya, dan atas dasar suatu kriteria menentukan satu pilihan di antara tujuan-tujuan yang saling bersaingan, lalu individu menilai alat yang mungkin dapat dipergunakan untuk mencapai tujuan (Jochnson, 1994).

Hal ini tercermin bahwa Yayasan SINAI mempunyai tujuan dalam melakukan pembinaan. Tujuan dari Yayasan SINAI adalah ikut serta membantu pemerintah dalam rangka mewujudkan pembangunan nasional di bidang sosial masyarakat dan bidang kerohanian. Membuat pembinaan bagi penghuni Yayasan SINAI adalah cara untuk mencapai tujuan tersebut, baik pembinaan mental spiritual, pembinaan ketrampilan, maupun pembinaan kedisiplinan. Hasil penelitian tersebut sesuai dengan Max Weber dalam Ritzer (1995), rasional instrumental merupakan tindakan sosial yang dilakukan seseorang didasarkan atas pertimbangan dan pilihan sadar yang berhubungan dengan tujuan tindakan itu dan ketersediaan alat yang dipergunakan untuk mencapainya.

Tindakan sosial yang digunakan Pembina adalah rasionalitas yang berorientasi nilai (Werk Rational). Tujuan para Pembina melakukan pembinaan adalah untuk melakukan pelayanan pada Tuhan dan membantu sesama manusia, yang mana nilai-nilai tersebut sesuai dalam ajaran agama. Cara yang digunakan untuk mencapai tujuan adalah dengan melakukan pembinaan-pembinaan untuk para penghuni Yayasan SINAI. Hasil penelitian diatas sesuai dalam Jochnson (1994) yang menyatakan bahwa alat-alat yang ada hanya merupakan pertimbangan dan perhitungan yang sadar, sementara tujuan-tujuannya sudah ada didalam hubungannya dengan nilai-nilai individu yang bersifat absolute atau merupakan nilai akhir baginya. individu mempertimbangkan alat untuk mencapai nilai-nilai seperti itu, tetapi nilainilai itu sendiri sudah ada.

Tabel 4.8. Bentuk Tindakan Sosial Dalam Melakukan Pembinaan

\begin{tabular}{|c|c|c|}
\hline Cara & Tujuan & Jenis Tindakan Sosial \\
\hline \multirow[t]{2}{*}{$\begin{array}{l}\text { Membuat } \\
\text { pembinaan- } \\
\text { pembinaan } \\
\text { bagi } \\
\text { penghuni } \\
\text { Yayasan } \\
\text { SINAI }\end{array}$} & $\begin{array}{l}\text { Ikut serta membantu } \\
\text { pemerintah dalam rangka } \\
\text { mewujudkan pembangunan } \\
\text { nasional di bidang sosial } \\
\text { masyarakat dan bidang } \\
\text { kerohanian (YAYASAN) }\end{array}$ & $\begin{array}{l}\text { Rasionalitas Instrumental (Zwerk } \\
\text { Rational) => tindakan sosial yang } \\
\text { dilakukan seseorang didasarkan atas } \\
\text { pertimbangan dan pilihan sadar yang } \\
\text { berhubungan dengan tujuan tindakan itu } \\
\text { dan ketersediaan alat (cara) yang } \\
\text { dipergunakan untuk mencapainya. }\end{array}$ \\
\hline & $\begin{array}{l}\text { Untuk melakukan pelayanan } \\
\text { pada Tuhan dan membantu } \\
\text { sesama } \\
\text { (PEMBINA) }\end{array}$ & $\begin{array}{l}\text { Rasionalitas yang berorientasi nilai } \\
\text { (Werk Rational) => tindakan sosial yang } \\
\text { dilakukan seseorang mempertimbangkan } \\
\text { alat (cara) untuk mencapai nilai-nilai } \\
\text { (tujuan) yang bersifat absolut, tetapi } \\
\text { nilai-nilai itu sendiri sudah ada. }\end{array}$ \\
\hline
\end{tabular}




\section{KESIMPULAN}

Jenis kenakalan yang dilakukan oleh anak-anak penghuni Yayasan SINAI dapat digolongkn menjadi 2, yaitu tindakan nonconform dan tindakan Tindakan nonconform meliputi melarikan diri dari rumah atau dari yayasan dan membolos sekolah. Tindakan anti sosial atau asocial meliputi tidak membayar tiket atau biaya transport saat naik kendaraan umum dan menumpang kendaraan-kendaraan besar yang melintas di jalan. Dan merupakan kenakalan terisolir (delinkuensi terisolir), kelompok ini merupakan jumlah terbesar dari remaja nakal. Pada umumnya mereka tidak menderita kerusakan psikologis.

Penyebab anak melakukan kenakalan berasal dari internal maupun dari eksternal. Faktor internal, yaitu adanya keinginan dari dalam dirinya sendiri. Melarikan diri dari rumah atau yayasan karena dari dalam dirinya memiliki keinginan untuk pergi dan membolos sekolah karena dirinya malas berangkat ke sekolah. Faktor eksternal, meliputi lingkungan keluarga yang membuat dia tertekan atau terancam, keadaan ekonomi, dorongan juga dari teman-teman yang juga ingin meninggalkan rumah, dan karena ikut-ikutan teman. Pembinaan yang dilakukan Yayasan SINAI yaitu pembinaan mental spiritual yang dilaksanakan dengan pembelajaran keagamaan, pembinaan ketrampilan dan kedisiplinan.

Faktor pendorong bagi Pembina yaitu karena adanya keyakinan dari dalam diri bahwa membina anak-anak yang membutuhkan merupakan ibadah dan keyakinan bahwa sesama manusia itu harus saling membantu. Sedangkan faktor pendorong bagi anak untuk mengikuti pembinaan yaitu karena adanya fasilitas yang lengkap dan layak untuk tempat tinggal serta terpenuhinya kebutuhan sehari-hari, adanya akses pendidikan dan adanya teman atau saudara. Faktor penghambat bagi Pembina yaitu karena adanya tingkah laku yang aneh dan terkadang juga terjadi kecelakaan saat membina atau pun merawat. Sedangkan faktor penghambat bagi anak-anak yang mengikuti pembinaan yaitu karena sikap Pembina yang tegas.

\section{DAFTAR PUSTAKA}

Anonim. 2002. Undang-Undang Nomor 23 tahun 2002 tentang Perlindungan Anak. Lembaran RI Tahun 2002 Nomor 109. Jakarta: Sekretariat Negara.

Creswell, J. W. 2010. Research design: pendekatan kualitatif, kuantitatif, dan mixed. Yogjakarta: PT Pustaka Pelajar.

Fenomena Klitih, Potret Kenakalan Remaja Yang Mengkhawatirkan diakses dari https://plus.kapanlagi.com/fenomena-klitih-potret-kenakalan-remaja-yangmengkhawatirkan-f90439.html, pada 9 November 2018

Jochnson, Doyle Paul. 1994. Teori Sosiologi Klasik dan Modern. Jakarta: Gramedia Pustaka.

Kartono, Kartini. 2014. Patologi Sosial Jilid 2: Kenakalan Remaja. Jakarta: PT. Raja Grafindo Persada.

KPAI : Riset Kekerasan di Media Picu Anak Jadi Pelaku Kejahatan tersedia di http://www.kpai.go.id/berita/kpai-riset-kekerasan-di-media-picu-anak-jadi-pelakukejahatan, diakses pada 9 November 2019

Miles, B. Mathew dan Huberman, A. Michael. 1992. Analisis Data Kualitatif Buku Sumber Tentang Metode-metode Baru. Jakarta: UIP.

Moleong, Lexy J. 2010. Metodologi penelitian kualitatif. Bandung: Remaja Rosdakarya.

Narwoko, J. Dwi dan Suyanto, Bagong. 2007. Sosiologi Teks Pengantar dan Terapan. Jakarta: Kencana

Simanjuntak, B., dan Pasaribu, I. L. 1990. Membina dan Mengembangkan Generasi Muda. Bandung: Tarsito.

Sugiyono. 2013. Metode Penelitian Pendidikan Pendekatan Kuantitatif, Kualitatif, dan R\&D. Bandung: Alfabeta. 